\title{
PERBEDAAN KUMUR CHLORHEXIDINE TERHADAP SKOR GINGIVITIS PASIEN ORTHO CEKAT USIA 15-30 TAHUN DI PRAKTEK Drg.SOFYAN MAKASSAR
}

\author{
PARIATI ${ }^{1}$, JOHNNY ANGKI닌 \\ ( ${ }^{1}$ Stikes Amanah Makassar, ${ }^{2}$ Poltekkes Kemenkes Makassar)
}

\begin{abstract}
ABSTRAK
Chlorhexidine merupakan salah satu obat kumur yang poten dan mempunyai antibakteri dengan spektrum luas. Perawatan orthodontic, termasuk fixed orthodontic (ortho cekat) dewasa ini sering digunakan seiring meningkatnya pengetahuan masyarakat. Gingivitis adalah suatu penyakit periodontal, biasa nya disebabkan oleh mikroorganisme plak dan produknya yang mengakibatkan terjadinya inflamasi dan infeksi yang menghancurkan jaringan pendukung gigi termasuk gingiva, ligament periodontal, tulang alveolar. Adanya piranti fixed orthodontic yang menempel pada gigigigi akan menyulitkan untuk membersihkan gigi sehingga cenderung terjadi penumpukan plak pada gigi sekitar bracket dan sepertiga mahkota gigi pada tepi gingiva. Kebersihan gigi dan mulut yang baik dapat dimaknai bahwa gigi dan mulut terbebas dari adanya debris, kalkulus, plak atau material asing lainnya.Penelitian ini bertujuan untuk mengetahui perbedaan kumur chlorhexidine terhadap skor gingivitis pasien ortho cekat usia 15-30 tahun di praktek Drg. Sofyan Makassar. Sampel diperoleh dari popilasi yang berjumlah 30 subjek gingvitis yang menggunakan ortho cekat. Kumur dilakukan di rumah selama 7 hari dengan 2 kali kumur setiap hari yaitu setelah subjek sikat gigi pada pagi hari dan setelah subjek sikat gigi sebelum tidur malam. Kemudian dianalisis menggunakan ujin statistik Paired sample $T$ Test. Berdasarkan analisis statistik terjadi penurunan derajat gingivitis dan ada perbedaan kumur chlorhexidine terhadap skor gingivitis pasien ortho cekat, setelah kumur dengan chlorhexidine.
\end{abstract}

Kata Kunci : Chlorhexidine, Gingivitis, Ortho Cekat

PENDAHULUAN

Obat kumur (mouthrinses)

digunakan sebagai agen kosmetik yang efektif dan agen terapeutik dalam mulut. Obat kumur tersedia dalam bentuk cair dan merupakan metode tradisional untuk menstabilkan dan membawa berbagai agen farmasetikal ke permukaan gigi dan jaringan untuk memberikan efek perawatan. Manfaat obat kumur terutama berfungsi sebagai penyegar nafas dan menjaga kebersihan mulut.

Gingivitis adalah suatu penyakit periodontal, biasannya disebabkan oleh mikroorganisme plak dan produknya yang mengakibatkan terjadinya inflamasi dan infeksi yang menghancurkan jaringan pendukung gigi termasuk gingiva, ligament periodontal, tulang alveolar. Keadaan yang bisa menjadi resiko berkembangnya gingivitis misalnya terjadi luka atau trauma pada gusi termasuk kesalahan menyikat gigi, perubahan hormonal (kehamilan atau pubertas), diabetes yang tidak terkontrol dan penyakit sistemik dan kesehatan mulut yang buruk. Keadaan gigi yang tidak beraturan, dan alat-alat yang kotor berada di dalam mulut seperti alat orthodontic atau gigi tiruan dapat pula mengiritasi gingiva dan meningkatkan resiko gingivitis.

Piranti fixed orthodontic memiliki bentuk yang rumit sehingga mempermudah melekatnya plak lebih lama dan dapat meningkatkan resiko karies,gingivitis dan kemungkinan terjadinya penyakit periodontal. Perawatan ini akan menimbulkan berbagai masalah khususnya dalam memelihara kesehatan gigi dan mulut.

Penelitian ini bertujuan untuk mengetahui perbedaan kumur chlorhexidine terhadap skor gingivitis pada pasien ortho 
cekat usia 15-30 tahun di praktek Drg.Sofyan Makassar.

Hasil dari penelitian ini diharapkan dapat menambah wawasan ilmu pengetahuan tentang penggunaan kumur chlorhexidine terhadap skor gingivitis di poli gigi bagi mahasiswa Politeknik Kesehatan Yogyakarta Jurusan Keperawatan Gigi dan dapat memberikan informasi tentang perbedaan kumur chlorhexidine dengan kumur air terhadap penurunan skor gingivitis pada pasien ortho cekat..

Chlorhexidine $0.2 \%$ juga dapat mempengaruhi jumlah koloni bakteri saliva karena bahan ini mengandung fenol. Secara lokal fenol memberikan efek bakteriostatik pada kadar $0,1-1 \%$, bersifat bakteriosid pada kadar $0.4-1,6 \%$ dan bersifat fungsidal pada kadar1,3\%. Kandungan bahan dasar chlorine pada chlorhexidine merupakan desinfektan tungkat tinggi, karena sangat aktif pada semua bakteri, virus, fungi, parasit dan beberapa spora. Keunggulan chlorhexidine terhadap bahan lain adalah kemampuan mengikatnya yang sangat kuat dalam rongga mulut. Berdasarkan hal tersebut, bahan ini membantu fasilitas pemeliharaan yang lebih lama dibandingan antibakteri yang lain dan dapat membatasi proliferasi bakteri. Efek antiseptik dari chlorhexidine tidak hanya bakteriostatik tetapi juga mempunyai daya lekat yang lama pada permukaan gigi, sehingga memungkinkan efek bakterisid (Agusmawanti, 2011).

Manfaat obat kumur terutama berfungsi sebagai penyegar nafas dan menjaga kebersihan mulut. Dua kategori yang telah diakui oleh American Dental Association (ADA) adalah bahwa obat kumur efektif melawan plak dan gingivitis. Kategori pertama berisi minyak esensial sebagai bahan aktif, sedangkan kategori lainnya yaitu produk yang mengandung chlorhexidine sebagai agen aktif. Obat kumur tersedia dalam berbagi rasa, aroma, warna dan memberikan sensasi nyaman untuk digunakan (Harris, 2004).

Chlorhexidine mempunyai pengaruh yang luas terutama untuk bakteri Gram positif dan Gram negatif, bakteri ragi juga jamur. Pada $\mathrm{pH}$ fisiologis chlorhexidine mengikat bakteri dipermukaan rongga mulut tergantung konsentrasinya, dapat bersifat bakteriostatik atau bakterisid. Sifat bakteriostatik bila konsentrasi antara 432 ug/ $\mathrm{m} 1$,konsentrasi yang lebih tinggi akan menyebabkan efek bakterisid, karena terjadinya presipitasi protein sitoplasma. Efek bakterisid kurang penting dibandingkan dengan efek bakteriostatik. Hambatan pertumbuhan plak oleh chlorhexidine dihubungkan dengan sifat chlorhexidine untuk membentuk ikatan dengan komponenkomponen pada permukaan gigi. Ikatan tersebut terjadi 1530 detik setelah kumur dan lebih dari $1 / 3$ bagian chlorhexidine diserap dan melekat, namun jumlah pelekatan sebanding dengan konsentrasinya (Prijantojo, 1996).

Gingivitis adalah peradangan pada jaringan gusi yang merupakan tahap awal dari penyakit periodontal. Kondisi ini disebabkan oleh iritasi plak yang biasanya menumpuk dipinggiran gusi. Apabila plak tidak dibersihkan, bakteri-bakteri didalamnya akan menghasilkan toksin atau racun yang akan mengiritasi gusi sehingga gusi akan mengalami peradangan. Biasanya kondisi ini diketahui dari gusi yang terlihat berwarna merah, membengkak dan mudah berdarah apabila menyikat gigi atau flossing. Gigi tersebut masih bisa berdiri dengan kokoh 
karena kerusakan belum mencapai jaringan periodontal yang lebih dalam. Apabila kondisi ini langsung dirawat, maka gusi akan kembali sehat seperti semula (Rahmadhan, 2010).

Gingivitis juga merupakan suatu bentuk penyakit periodontal, biasanya disebabkan oleh mikroorganisme plak dan produknya, terjadi 2-4 hari setelah plak berakumulasi dan berkontak dengan ephitel gingiva, mengakibatkan terjadinya inflamasi dan infeksi yang menghancurkan jaringan pendukung gigi termasuk gingiva, ligament periodontal, tulang alveolar. Keadaan yang biasa menjadi resiko berkembangnya gingivitis misalnya terjadi luka atau trauma pada gusi termasuk kesalahan menyikat gigi, perubahan hormonal (kehamilan atau pubertas), diabetes yang tidak terkontrol dan penyakit sistemik dan kesehatan mulut yang buruk. Keadaan gigi yang tidak beraturan, ujung tumpatan yang kasar dan alat-alat yang kotor berada di dalam mulut seperti alat orthodontic atau gigi tiruan dapat pula mengiritasi gingiva dan meningkatkan resiko gingivitis (Malik, 2008).

a. Inflamasi

Inflamasi adalah respon perlindungan tubuh dengan tujuan utama untuk membersihkan baik penyebab awal kerusakan pada sel seperti mikroba dan racun maupun hasil dari perusakan sel seprti sel mati dan jaringan yang mati lainnya (Robbins dkk, 1995). Reaksi inflamasi lokal meliputi dua fase yaitu, penghancuran dan penghilangan faktor iritan dan perbaikan jaringan. Penyebab reaksi inflamasi sendiri dibagi menjadi reaksi yang bersifat vital yaitu oleh bakteri dan virus, serta non vital oleh trauma, benda asing, perubahan suhu serta tekanan (Miller, 2006).

b. Mekanisme patologis gingivitis

Perubahan patologis gingivitis ditunjukan dengan adanya mikroorganisme pada sulkus gingiva. Organisme tersebut akan mensintesis produk yang berbahaya yang akan merusak sel epitel dan jaringan ikat, serta juga unsur interselulair seperti kolagen, substansi dasar, dan glikokaliks. Perkembangan gingivitis diketegorikan dalam tiga tahap utama yang tidak terputus antara tahap satu dengan tahap yang lainnya, sementara tahap keempat sudah termasuk tahap periodontitis (Carranza, 1990).

Gingivitis dimulai dari lesi awal, perubahan terlihat pertama kali disekitar pembuluh gingiva yang kecil, disebelah apikal dari epitelium jungsional. Pembuluh ini mulai bocor dan kolagen perivaskular mulai menghilang, digantikan dengan beberapa sel inflamasi, sel plasma dan limfosit terutama Limfotit $\mathrm{T}$ - cairan jaringan dan protein serum. Disini terlihat tingkatan migrasi leukosit melalui epitelium jungsional dan eksudat cair dari jaringan dari leher gingiva.selain meningkatnya aliran eksudat cairan dari PMN (leukosit polimorfonuklear) tidak terlihat adanya tanda-tanda klinis dari perubahan jaringan pada tahap penyakit ini (Manson, dkk, 1993). 
Tabel 1. Indeks gingiva oleh Loe dan Silness, 1963; cit.Manson dan Eley, 1993).

\begin{tabular}{cl}
\hline Skor & \\
\hline 0 & Gingiva normal \\
& (warna merah muda, interdental papilla mengisi interproximal space sampai titik \\
& kontak berbentuk sudut lancip, permukaan gingival tidak rata(stipled), bagian \\
& margin tipis, tidak bengkak, sulkus gingival tidak dalam, tidak ada eksudat, tidak \\
& mudah berdarah). \\
& Inflamasi ringan, sedikit perubahan warna, sedikit oedema. Tidak ada perdarahan \\
& waktu penyondean \\
\hline 2 & Inflamasi sedang, kemerahan, oedema, dan mengkilat. Perdarahan pada waktu \\
& penyondean \\
\hline 3 & Inflamasi parah, kemerahan yang nyata dan oedema, ulserasi. Kecenderungan \\
& perdarahan spontan
\end{tabular}

Alat ortodonti cekat (kawat dan band) merupakan tempat yang baik bagi pertumbuhan bakteri dan tentunya ikut andil secara nyata dalam proses terjadinya inflamasi. Splin ekstrakoronal sementara, baik tersusun dari band ortodonti yang di solder, kawat dan resin akrilik, juga termasuk dalam kategori ini. Pada akhirnya, terbukti bahwa kekeliruan/kesalahan tindakan kedokteran gigi dalam semua bidang dapat menciptakan tempat berakumulasinya plak, meningkatkan produknya dan mempersulit pembersihan mekanis (Peter, dkk, 2005).

Pada awal pemakaian alat orthodontic cekat banyak pasien yang mengeluhkan adanya peradangan pada rongga mulutnya. Kerusakan fisik pada mukosa mulut dapat disebabkan oleh permukaan tajam dari klamer atau tepi-tepi peralatan orthodontik yang dipakai. Berdasarkan observasi pada orthodontisi sebagian besar pemakai alat orthodontik terutama pada awal didikuti peradangan pada jaringan lunaknya, salah satunya adalah gingivitis yang paling rutin ditemui. Adanya kekuatan tarik dan geser dari alat yang dipakai sangat berpengaruh terhadap jaringan periodontalnya. Biasanya diawali dengan gingivitis ringan hingga berat. Ketelitian dalam membersihkan gigi secara mekanis (menyikat gigi) diperlukan perlakuan ekstra pada pemakai alat orthodontic (Yordan, dkk, 2003; cit. Yohana, 2007).

Perawatan orthodonsi aktif mencakup pemakian pesawat. Setiap pesawat yang di pakai di dalam mulut, tak peduli betapa teliti desainnya dan ketepatannya, berpotensi untuk menimbulkan penyakit gigi dan periodontal. Pemakaian pesawat cekat menimbulkan kerusakan pendukung periodontal yang meskipun sedikit namun irevesibel (Hollender dkk, 1980; cit.Hamp dkk, 1982). Perawatan orthodonsi tersebut dapat menggunakan alat cekat maupun lepasan. Alat orthodontik cekat mempunyai 3 komponen yaitu bracket,archwire,dan asesoris, yang ketiganya saling berhubungan. Bracket memberikan titik perlekatan pada mahkota gigi sehingga archwire dan assesorisnya dapat mempengaruhi posisi. Jaringan periodontal menumpu gigi yang bergerak akibat pengaktifan alat orthodontik. Kekuatan yang 
berlebihan dapat mengakibatkan inflamasi yang parah pada jaringan periodontal (Yordan, dkk, 2003; cit.Yohana, 2007).

\section{Metode Penelitian}

Penelitian ini menggunakan desain Quasi eksperimen dengan rancangan Pre Test-Post Test ${ }^{4}$ kelompok perlakuan dengan kelompok kontrol. Populasi dalam penelitian ini yakni pasien ortho yang gingivitis, baik laki-laki maupun perempuan usia 15-30 tahun dan telah memakai ortho cekat sejak April 2011 - Juni 2012.

Pada rancangan ini dilakukan Randomisasi, artinya anggota-anggota kelompok eksperimen atau kontrol dilakukan secara acak (random), kemudian dilakukan pre test pada kedua kelompok (eksperimen dan kontrol).Pada Randomisasi (R) dua kelompok, mendapat kesempatan yang sama untuk dipilih sebagai sampel sebelum dilakukan perlakuan. Oleh karena kedua kelompok mendapatkan kesempatan yang sama pada awal sebelum dilakukan perlakuan, hasil perlakuan pada post test (02) yang diharapkan ada perbedaannya
Pengambilan sampel dalam penelitian ini dilakukan pada 30 subjek yang memakai ortho cekat. Penelitian ini menggunakan teknik simple random sampling yakni didasarkan pada suatu pertimbangan tertentu yang dibuat oleh peneliti tersendiri berdasarkan ciri atau sifat populasi yang sudah diketahui sebelumnya.

\section{Hasil Penelitian}

Telah dilakukan penelitian yang bertujuan untuk mengetahui perbedaan kumur chlorhexidine terhadap skor gingivitis pasien ortho cekat usia 15-30 tahun di praktek Drg.Sofyan Makassar. Pengukuran dilakukan pada 30 subjek yang dibagi menjadi 2 kelompok yaitu 15 kelompok kontrol yang berkumur dengan air dan 15 kelompok perlakuan yang berkumur dengan chlorhexidine. masing-masing kelompok terdiri atas 15 sampel. Hasil pengukuran skor gingivitis dilakukan dengan cara melakukan pengukuran Index Gingiva menurut Loe dan Silness yang terlihat pada Tabel 1 .

Tabel 1. Distribusi Frekuensi Responden Kumur Chlorhexidine Berdasarkan Jenis Kelamin

\begin{tabular}{ccccc}
\hline Jenis Kelamin & Jumlah & Prosentase & \\
laki-laki & 4 & 26.7. & \\
perempuan & 11 & 73.3 & \\
\hline Jumlah & 15 & 100.0 & \\
\hline \multirow{2}{*}{ Berdasarkan Tabel 1 dapat dilihat, bahwa } & $26,7 \%$ & berjenis & kelamin laki-laki.
\end{tabular}


Tabel 2. Distribusi Frekuensi Responden Kumur Air Berdasarkan Jenis Kelamin

\begin{tabular}{ccc}
\hline Jenis Kelamin & Jumlah & Prosentase \\
\hline laki-laki & 6 & 40.0 \\
perempuan & 9 & 60.0 \\
\hline Jumlah & 15 & 100.0 \\
\hline
\end{tabular}

Berdasarkan Tabel 2. Diketahui bahwa

$60 \%$ berjenis kelamin perempuan dan $40 \%$ jumlah responden yang kumur air sebanyak

berjenis kelamin laki-laki.

Tabel 3. Distribusi Frekuensi Pasien Kumur Chlorhexidine Berdasarkan Usia

\begin{tabular}{ccc}
\hline Usia & Jumlah & Prosentase \\
\hline $10-15$ tahun & 0 & 0 \\
$16-20$ tahun & 5 & 33.4 \\
$21-25$ tahun & 6 & 39.3 \\
$26-30$ tahun & 4 & 26.8 \\
\hline Jumlah & 15 & 100.0 \\
\hline
\end{tabular}

Berdasarkan Tabel 3. Diketahui bahwa responden yang berkumur dengan chlorhexidine yang paling banyak dalah usia 21-25 sebanyak $39.3 \%$ dari 15 responden.

Tabel 4. Distribusi Frekuensi Pasien Kumur Air Berdasarkan Usia

\begin{tabular}{ccc}
\hline Usia & Jumlah & Prosentase \\
\hline $10-15$ tahun & 4 & 26.7 \\
$16-20$ tahun & 3 & 20.0 \\
$21-25$ tahun & 6 & 44.1 \\
$26-30$ tahun & 2 & 13.4 \\
\hline Jumlah & 15 & 100.0 \\
\hline
\end{tabular}

Berdasarkan Tabel 4. Dapat yang diperiksa sebelum dilakukannya diketahui bahwa jumlah responden yang perlakuan berkumur dengan chlorhexidine. paling banyak adalah usia 21-25 tahun yang Berdasarkan kriteria tersebut diketahui berjumlah $44.1 \%$ dari 15 responden.

Dari seluruh responden penelitian sebanyak 30 responden yang menderita gingivitis ringan maupun sedang dan dapat masing-masing mempunyai kriteria gingivitis dilihat dari tabel dibawah ini: 
Tabel 5. Distribusi Frekuensi Skor Gingivitis Responden Sebelum dan Setelah Kumur Chlorhexidine dan Kumur Air

\begin{tabular}{clrl}
\hline Variabel & $\begin{array}{l}\text { Rata-rata } \\
\text { gingivitis skor } \\
\text { kumur }\end{array}$ & $\begin{array}{l}\text { Rata-rata gingivitis } \\
\text { setelah kumur }\end{array}$ & $\begin{array}{l}\text { Selisih rata-rata } \\
\text { skor gingivitis }\end{array}$ \\
\hline Chlorhexidine & 0.9667 & 0.5187 & 0.4480 \\
Air & 0.8660 & 0.9287 & -0.0627 \\
\hline
\end{tabular}

Berdasarkan Tabel 5. Menunjukkan bahwa rata-rata skor gingivitis responden sebelum kumur chlorhexidine adalah 0.9667 dan setelah kumur chlorhexidine rata-rata skor gingivitis adalah 0.5187 . sedangkan rata-rata skor gingivitis sebelum kumur air adalah 0.8660 dan setelah kumur air adalah -0.0627. Hal ini menunjukkan adanya penurunan skor gingivitis setelah kumur chlorhexidine dibandingkan dengan kumur air.
Perbedaan kumur chlorhexidine terhadap skor gingivitis pasien ortho cekat usia 15-30 tahun di praktek Drg.Sofyan Makassar, selanjutnya diuji statistik menggunakan uji Paired Sample T Test untuk mengetahui peebedaan kumur chlorhexidine terhadap skor gingivitis. Hasil analisis data dengan Paired Sample T Test dapat dilihat pada tabel berikut:

Tabel 6. Hasil Uji Statistik Peired Sample T Test Sebelum dan Setelah Kumur Chlorhexidine dan kumur Air.

\begin{tabular}{|c|c|c|c|c|}
\hline Variabel & $\bar{T}$ & Df & Siq & $P$ \\
\hline $\begin{array}{l}\text { Sebelum dan } \\
\text { setelah kumur }\end{array}$ & 5.657 & 14 & 0.000 & 0.05 \\
\hline
\end{tabular}

$\begin{array}{lllll}\text { Sebelum dan } & -1.111 & 14 & 0.285 & 0.05\end{array}$

setelah kumur air

Pada Tabel 6. Berdasarkan uji Paierd Sample $T$ Test diketahui bahwa $\mathrm{p}$-valule yaitu 0.000 lebih kecil 0.05 ( $p$-value<0.05), maka $\mathrm{HO}$ ditolak, Ha diterima berarti ada perbedaan kumur chlorhexidine terhadap skor gingivitis pada pasien ortho cekat. Dengan demikian hasil analisis ini mendukung pernyataan penelitian bahwa terjadi perbedaan yang bermakna antara perubahan skor gingivitis sebelum dan setelah kumur chlorhexidine pada pasien ortho cekat. 


\section{Pembahasan}

Penurunan gingivitis ini menunjukkan adanya perbedaan setelah berkumur dengan chlorhexidine sebagai antibiotik dan anti inflamasi. Pada penelitiaan ini, setelah kelompok perlakuan kumur dengan kumur chlorhexidine sebanyak 2 kali sehari dalam 7 hari menunjukkan gingivitis akhir menjadi 0.5187. Perbedaan skor gingivitis setelah kumur pada hasil penelitian ini disebabkan karena chlorhexidine adalah salah satu obat kumur yang poten.

Penelitian yang dilakukan ini menunjukkan skor gingivitis sebelum dilakukan kumur dengan chlorhexidine adalah 0.9667 sedangkan setelah kumur chlorhexidine adalah 0.5187, dapat dilihat pada Tabel 5. Hasil penelitian ini menunjukkan bahwa ada perbedaan skor gingivitis yang terjadi setelah kumur dengan chlorhexidine.

Penelitian ini didukung oleh penelitian yang dilakukan bahwa obat kumur yang paling efektif adalah chlorhexidine $0,2 \%$ karena paling banyak menurunkan jumlah koloni bakteri saliva., Persamaan dari penelitian ini yaitu menggunakan obat kumur chlorhexidine sebagai perlakuan.

Penelitian yang dilakukan oleh juga menunjukkan bahwa larutan 0,2\% chlorhexidine sebagai obat kumur selama 1 minggu menyebabkan penurunan indeks radang gingiva pada hari ke 7 yakni sebanyak $72 \%$ pada hari ke 3 dan $85 \%$

\section{DAFTAR PUSTAKA}

Agusmawanti, P. 2011. Perbandingan Daya Antibakteri Kumur Rebusan Gambir (Uncaria gambir) dengan Chlorhexideine 0,2 \% Terhadap Jumlah Koloni Bakteri Saliva. Jurnal majalah ilmiah Sultan Agung: Unissula. pada hari ke 7. Sangat efektif mengurangi radang gingiva dan akumulasi plak, pendapat ini sesuai dengan pendapat bahwa larutan chlorhexidine sangat efektif digunakan untuk plak kontrol pada perawatan radang gingivitis.ditersebut menggunakan chlorhexidine $0,2 \%$ selama 7 hari dan sangat sefektif mengurangi radang gingivitis.

Pernyataan ini diperkuat oleh penelitian yang dilakukan yang menunjukkan bahwa klorheksidin mampu menghambat pembentukan plak dan mencegah terjadinya gingivitis. Namun karena adanya efek samping penggunaan khlorheksidin maka beberapa negara telah memasarkan obat kumur yang mengandung klorheksidin 0.12 $\%$ (Peridex dan Periogard).

\section{Kesimpulan}

1. Sebelum kumur chlorhexidine, skor gingivitis pengguna ortho cekat adalah 0.9667 .

2. Setelah kumur chlorhexidine, skor gingivitis pengguna ortho cekat adalah 0.5187 yang berarti mengalami penurunan skor gingivitis setelah kumur chlorhexidine.

\section{Saran}

Berdasarkan hasil dari penelitian ini maka chlorhexidine dapat dijadikan pilihan bagi pengguna ortho sebagai pilihan obat kumur untuk mengurangi dan mencegah terjadinya gingivitis

Ehwarieme, D. A., Ohwe-Ureghe, U. B., D. O. Ebeh., 2010., Antibacterial Activity of Garlic and Lime on Isolates of Extracted Carious Teeth African Journal of Biotechnologi, 9 (21):3163-66.

Fitriastuti, P., 2011. Efek Chlorhexidine terhadap Resiko Karies ditinjau dari pH Plak dan Efek pH Saliva pada pasien yang Menggunakan Alat 
Orthodonti Cekat. Jakarta: Universitas Indonesia.

Forest, A. P., \& Corter, D. C., 1995. Principle and Pratice of Surgery, Edisi III, Churchill Living Stone, Edinburg.

Gaffar, A., \& Volpe, A. R., 2004. Inflammation Periodontal Disease, and Systemic Health in A Supplement to Compendum of Continuing Education in Dentistry: Gingivitis: An Inflamatory Periodontal Diasease, Medical World Bussiness Press Inc., Jamesburg.

Horax, M.P. 2011. Efektifitas larutan Klorhexidin $0.2 \%$ dan Povidon lodida $1 \%$ terhadap penurunan indeks plak pada pemakai alat ortodontik cekat. Makassar: Universitas Hasanuddin.

Malik, I. 2008. Kesehatan Gigi Untuk Keluarga Bagian Orthodonti. Fakultas Kedokteran Gigi Universitas Padjajaran Bandung.

Miller, C. S., King, C. P, Langub, M. C., kriscyo, R. J., Thomas, M. V., 2006, salivary Biomakers of Exiting Periodontal Disease: A CrossSectional Study, JADA, 137-329-9.
Naeswari, A., 2011. Perebedaan efektifitas obat kumur chlorhexidine tanpa alkohol dibandingkan dengan chlorhexidine beralkohol dalam menurunkan kuantitas koloni bakteri rongga mulut.

Nurdin, D., 2011. Sodium Alginat sebagai Controlled Release Mikroenkapsulasi Chlorhexidine 2\% untuk Alternatif Dressing Saluran Akar Gigi, (1) 3.

Peter, F. F., Arthur, R. V., John, L. G., 2005. Silabus Periodonti (The Periodontic Syillabus). 19, 40-43, 81-83.

Putri, M.H., Julianti, E.H., Nurjannah N, 2011. IImu Pencegahan Penyakit Jaringan Keras dan Jaringan Pendukung Gigi. 195-200.

Restanti H.P. 2011. Pengaruh Kumur Ekstrak Etanolik Bawang Putih (Allium Sativum L.) Terhadap Jumlah Leukosit Dalam Gingival Crevicular Fluid Pada Penderita Gingivitis Pengguna Fixed Orthodontic Appliances, Yogyakarta: Universitas Gadjah Mada. 